\title{
HPV infection and bacterial microbiota in the semen from healthy men
}



Heidi Tuominen ${ }^{*^{*}}$ D, Jaana Rautava ${ }^{1,2,3}$, Katja Kero $^{4}$, Stina Syrjänen ${ }^{1,5}$, Maria Carmen Collado ${ }^{6}$ and Samuli Rautava ${ }^{7,8}$

\begin{abstract}
Background: Aberrant microbiota composition has been linked to disease development at numerous anatomical sites. Microbiota changes in reaction to viral infections, such as human papillomavirus (HPV), have been investigated almost exclusively in the female reproductive tract. However, HPV infection may also affect male health by reducing semen quality and fertility. The aim of this study was to investigate whether present HPV DNA is associated with detectable changes in semen bacterial microbiota composition and diversity.

Methods: This study relied on stored semen samples from 31 fertile healthy men who participated in the Finnish family HPV Study during the years 1998-2001. DNA was extracted from semen with PCR template preparation kit. HPV was genotyped using Luminex-based Multimetrix ${ }^{\circledR}$ assay. Microbiota was analyzed from the V3-V4 region of $16 \mathrm{~S}$ rDNA gene following sequencing on an Illumina MiSeq platform. All statistical analyses were performed with Calypso software version 8.84 .

Results: HPV DNA was detected in 19.4\% (6/31) of the semen samples. HPV status in the semen did not impact the a-diversity estimations, as measured by Chao1 and Shannon indices, nor ß-diversity. Nevertheless, HPV-positive semen samples exhibited differences in the taxonomic composition of the bacterial microbiota including higher abundances of Moraxellaceae ( $p=0.028)$, Streptococcus $(p=0.0058)$ and Peptostreptococcus $(p=0.012)$ compared to HPV-negative semen samples.

Conclusion: HPV infection is associated with altered bacterial microbiota composition in semen, and this might have in impact to male health in general. As of present, it is unclear whether these changes result from HPV infection or whether altered bacterial microbiota increases susceptibility to HPV infection. More research is needed on viral-bacterial interactions in the male reproductive system.
\end{abstract}

Keywords: Bacteria, HPV, Men, Microbiome, Microbiota, Semen

\section{Background}

Human papillomavirus (HPV) is a known oncovirus and it has potential to cause carcinoma in the genital, anal and oropharyngeal regions [1]. The natural history of HPV is currently well known in the female cervical region as well as in the oropharyngeal region. Nonetheless, HPV can infect other body sites as well $[2,3]$.

\footnotetext{
* Correspondence: heemtu@utu.fi

'Department of Oral Pathology and Oral Radiology, Institute of Dentistry, Faculty of Medicine, University of Turku, Lemminkäisenkatu 2, FIN-20520 Turku, Finland

Full list of author information is available at the end of the article
}

Several studies have reported the presence of HPV DNA in $2-31 \%$ of semen samples from healthy men [4-7]. Luttmer et al. [8] found that the presence of HPV in semen was associated with the presence of HPV in the penile scrapes but not with flat penile lesions (FPL). Foresta et al. [9] found HPV16 proteins in peripheral blood leukocytes in individuals with HPVpositive seminal samples. Therefore, suggesting the presence of HPV in semen seems not to be only local. HPV in semen has been implicated in male infertility. A systematic review including 21 original articles, concluded that HPV DNA found in semen is connected

C C The Author(s). 2021 Open Access This article is licensed under a Creative Commons Attribution 4.0 International License, which permits use, sharing, adaptation, distribution and reproduction in any medium or format, as long as you give appropriate credit to the original author(s) and the source, provide a link to the Creative Commons licence, and indicate if changes were made. The images or other third party material in this article are included in the article's Creative Commons licence, unless indicated otherwise in a credit line to the material. If material is not included in the article's Creative Commons licence and your intended use is not permitted by statutory regulation or exceeds the permitted use, you will need to obtain permission directly from the copyright holder. To view a copy of this licence, visit http://creativecommons.org/licenses/by/4.0/. The Creative Commons Public Domain Dedication waiver (http://creativecommons.org/publicdomain/zero/1.0/) applies to the data made available in this article, unless otherwise stated in a credit line to the data. 
with reduced semen quality [10]. In a relatively recent study, women undergoing intrauterine insemination with HPV-positive semen were found to have four times fewer pregnancies than couples with HPVnegative semen [11]. To date, the association between the bacterial microbiota and HPV DNA in semen has yet remained unknown. Besides various factors, including sexual behavioural characteristics being determinant of the presence of HPV in semen particularly in adjusted analysis [8], other factors such as the semen microbiota could potentially impact the HPV status in semen. This speculation seems logical following the reports on concordance of HPV detection in semen and penile scrapes [8] and potential role of penile microbiota (specifically bacterial communities) on penile HPV infection [12]. Nonetheless, our knowledge about the interactions between HPV infection and the bacterial microbiota and its impact on human health is still limited.

Although limited, published literature in the last decade have given us a glimpse into the composition of semen microbiota. The semen microbiota is mainly composed of the genera Lactobacillus, Pseudomonas, Prevotella, Gardenella, Corynebacterium, Staphylococcus and Streptococcus [13-17]. Semen microbial composition has been associated with seminal health $[13,14$, 16]. HIV infection, prostatitis (inflammation of the prostate gland) and sexual intercourse can all elicit an impact to the microbial composition in semen $[12,15,16,18]$. According to previous studies, changes in the relative amount of different bacteria have been linked with semen quality $[13,14]$. However, not all studies have been able to observe differences in semen bacterial microbiota between fertile and infertile couples [14, 17]. This could be explained by differences in study design, study populations or methods.

Since it is known that seminal microbiota can influence fertility and even offspring health, it is important to understand aspects that might affect semen microbiota composition [19]. We investigated the prevalence in HPV positivity in a subset of samples from Finnish Family HPV Study and evaluated the association between HPV and bacterial microbiota in these semen samples.

\section{Methods}

Study design, study population and ethical consideration and consent

The subjects and samples of the present study were from a sub-set of subjects from the Finnish Family HPV Study collected during the years 1998-2001 [20, 21]. The original study was designed to evaluate the interactions of HPV infection within families. Written informed consent was obtained from all participants. The study design was found acceptable by the Ethics Committee of the
Intermunicipal Hospital District of Southwest Finland (\#3/1998, \#2/2006, 45/180/2010).

Semen samples for microbiota analyses were collected based on the placenta HPV status as previously described in detail [3]. The original inclusion criteria included 13 mothers wih HPV-positive placenta samples and 26 mothers with HPV-negative placenta samples (13 from caesarean section deliveries and another 13 from vaginal deliveries) in addition with male spouse and infant samples. Study subjects were excluded if some of the sample type was missing. Altogether, 31 semen samples from the male spouses were available for the present study. The sample selection and detailed information about the samples have been described in detail in Fig. 1, Table 1 and Supplementary Table 1.

Semen samples were collected during the female spouse's third trimester. The detailed sample collection is described earlier [4]. Semen sample was self-collected into a sterile plastic container from each of the participants after 2-10 days of abstinence (mean: 4.4 days). The sample was transferred to the laboratory and placed in $37^{\circ} \mathrm{C}$ for $30 \mathrm{~min}$ for liquefaction. The semen samples were centrifuged at $3500 \mathrm{rpm}$ for $15 \mathrm{~min}$ and cellular fraction (pellet) and seminal plasma (secretions without semen cells e.g. supernatant) were stored. The fractions were stored separately first at $-20^{\circ} \mathrm{C}$, and subsequently kept in $-70^{\circ} \mathrm{C}$. Only the cellular fraction was used for the present study and for HPV DNA detection.

\section{HPV detection and genotype}

Detailed description about the semen HPV DNA detection and genotyping is described earlier [7]. HPV DNA was extracted from frozen semen cellular fractions with the high purity polymerase chain reaction (PCR) template preparation kit (Roche Diagnostics, Switzerland), according to the manufacturer's instructions. For HPV testing, nested PCR was performed using MY09/MY11 as external primers and GP05+/bioGP06+ as internal primers, because viral load/cell and number of infected cells among the uninfected cells was expected to be low. HPV genotyping was performed using the Luminexbased Multimetrix ${ }^{\oplus}$ assay (Progen Biotechnik $\mathrm{GmbH}$, Heidelberg, Germany), which detects 24 HPV types; 6 low-risk genotypes (HPV6, 11, 42, 43, 44, and 70); 3 putative high-risk genotypes (HPV26, 53 and 66; and 15 high-risk genotypes (HPV16, 18, 31, 33, 35, 39, 45, 51, $52,56,58,59,68,73$ and 82). The assay was performed according to manufacturer's instructions except only half of the volume of the recommended volume was used. In the final step $100 \mathrm{ul}$ of the blocking buffer was used to measure the hybridized beads with Luminex LX-100 analyzer. The HPV genotypes of all of the male samples has been analyzed and reported earlier [7]. 


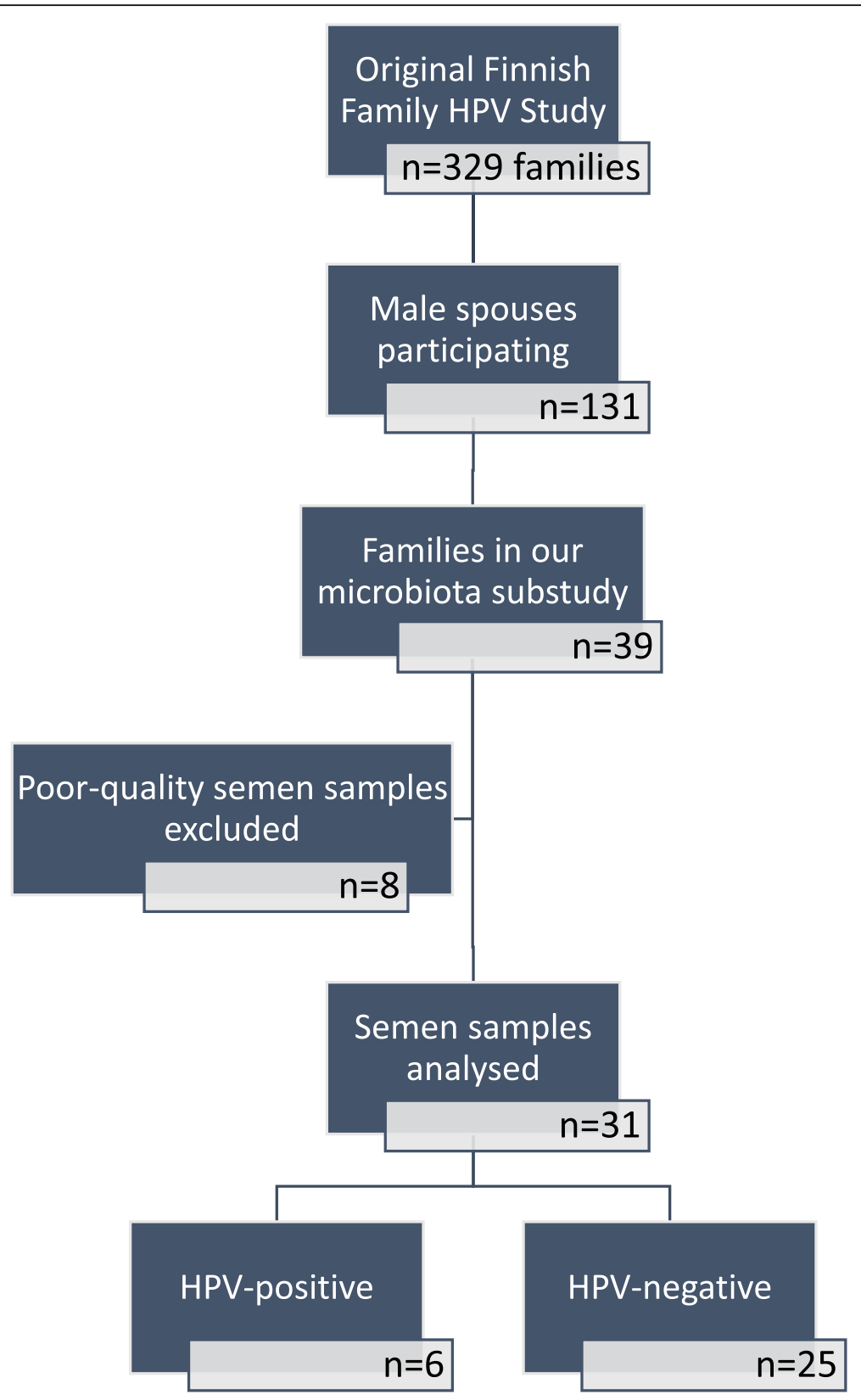

Fig. 1 A flow chart depicting sample selection from the original Finnish Family HPV study

16S rRNA gene sequencing and analysis

Sample analyzing methods have previously been described in detail [2, 3, 22]. Briefly, the V3-V4 region of $16 \mathrm{~S}$ rDNA gene was amplified following Illumina protocols using Nextera XT Index Kit (Illumina, San Diego, CA, USA). Libraries were sequenced on a MiSeq Illumina platform (Lifesequencing sequencing service, Valencia, Spain) and PCR amplification and library controls were sequenced along as negative controls to rule out and control any possible contaminations. Quality assessment of the raw sequence files was performed using FASTX-toolkit version 0.0.13 as described earlier [3]. An open-reference operational taxonomic unit (OTU) picking method using 99\% identity to the Greengenes 13_8 database [23] was performed using QIIME pipeline (version 1.9.0) [24]. Calypso software version 8.84 (http:// cgenome.net/calypso/) [25] was used with total sum normalization (TSS) combined with square root transformation for the differential analysis and diversity estimations. We considered $p$-values $\leq 0.05$ statistically significant. 
Table 1 The list of the samples

\begin{tabular}{|c|c|c|c|c|}
\hline ID & Male spouse's age-range (years) & Smoking & Semen (HPV type) & Female spouse's HPV status (genotype) \\
\hline 1 & $20-24$ & yes & - & oral (16) \\
\hline 2 & $20-24$ & no & - & - \\
\hline 3 & $30-34$ & yes & - & - \\
\hline 4 & $25-29$ & no & - & - \\
\hline 5 & $20-24$ & no & 18 & oral (16) \\
\hline \multirow[t]{2}{*}{6} & \multirow[t]{2}{*}{$20-24$} & \multirow[t]{2}{*}{ yes } & \multirow[t]{2}{*}{-} & oral (16) \\
\hline & & & & cervix $(16,33)$ \\
\hline 7 & $20-24$ & yes & - & - \\
\hline 8 & $30-34$ & yes & 6 & - \\
\hline 9 & $25-29$ & no & 6,33 & - \\
\hline 10 & $25-29$ & no & - & - \\
\hline 11 & $20-24$ & no & - & - \\
\hline 12 & $25-29$ & no & - & - \\
\hline 13 & $40-44$ & no & - & - \\
\hline 14 & $30-34$ & no & 33 & oral (16) \\
\hline 15 & $35-39$ & no & - & - \\
\hline 16 & $30-34$ & no & - & placenta (6) \\
\hline 17 & $25-29$ & yes & - & cervix $(16,31,66)$ \\
\hline 18 & $20-24$ & no & - & - \\
\hline 19 & $30-34$ & no & - & - \\
\hline \multirow[t]{2}{*}{20} & \multirow[t]{2}{*}{$25-29$} & \multirow[t]{2}{*}{ no } & \multirow[t]{2}{*}{-} & placenta (6) \\
\hline & & & & cervix $(6,59)$ \\
\hline 21 & $25-29$ & yes & - & - \\
\hline 22 & $35-39$ & no & 16 & - \\
\hline \multirow[t]{3}{*}{23} & \multirow[t]{3}{*}{$25-29$} & \multirow[t]{3}{*}{ no } & \multirow[t]{3}{*}{-} & oral (16) \\
\hline & & & & cervix (16) \\
\hline & & & & placenta (16) \\
\hline 24 & n.a. & n.a. & - & \\
\hline 25 & $25-29$ & no & - & \\
\hline \multirow[t]{3}{*}{26} & \multirow[t]{3}{*}{$30-34$} & \multirow[t]{3}{*}{ yes } & \multirow[t]{3}{*}{-} & oral (6) \\
\hline & & & & cervix (6) \\
\hline & & & & placenta (6) \\
\hline 27 & $20-25$ & yes & - & oral (58) \\
\hline 28 & $25-29$ & yes & - & - \\
\hline 29 & $30-34$ & no & 53 & oral (16) \\
\hline \multirow[t]{2}{*}{30} & \multirow[t]{2}{*}{$20-25$} & \multirow[t]{2}{*}{ no } & \multirow[t]{2}{*}{-} & oral $(6,16,42,56)$ \\
\hline & & & & placenta (6) \\
\hline 31 & $25-29$ & no & - & oral (16) \\
\hline
\end{tabular}

Men's age-ranges, smoking status and semen HPV status and genotype have been listed in addition with female spouse's HPV status of three anatomical regions (placenta, cervix, oral). The female genital and oral samples have been obtained during the 3rd trimester of pregnancy n.a. not available

\section{Results}

HPV detection in semen samples

HPV DNA was detected in 6 of the 31 semen samples (19.4\%). Infection with a single HPV genotype was found in five of the samples (HPV 16, 6, 18, 33 and 53; 3.2\% for each), as seen in Table 1 . Infection with multiple HPV types (HPV 6 and 33) was found in one case (3.2\%). 
None of the HPV DNA positive semen samples associated with female spouse's HPV status in oral, cervix or from the placenta as we did not observe the same HPV genotype in partners simultaneously.

\section{Microbiota and HPV in semen}

The predominant bacterial families detected in the semen samples consisted of Comamonadaceae (relative abundance 4.13\%), Bifidobacteriaceae (2.44\%), Tissirellaceae (2.39\%) and Corynebacteriaceae (2.11\%). In addition, Delftia (3.76\%), Unclassified Comamonadeceae (1.56\%), Propionibacterium (1.55\%) and Streptococcus (1.52\%) genera were detected. The most prevalent bacteria detected from HPV-negative and HPV-positive semen samples are presented in Supplementary Table 2.

HPV status in semen did not impact the alpha diversity estimations, as measured by two alpha diversity metrics: Chao1 (HPV-negative: 65 versus HPV-positive 75, $p=0.820$, Fig. 2a) and Shannon index (HPV-negative: 2.5 versus HPV-positive $3.3, p=0.058$, Fig. $2 \mathrm{~b}$ ), although there was a trend towards increased diversity with the latter metric. No differences were detected in beta diversity observed with principal coordinates analysis (PCoA) with Bray-Curtis distance (ADONIS $p=0.494$ ) or redundancy analysis (RDA, $p=0.506)$ as presented in the Supplementary Data 1.

Since there was no major impact to semen bacterial microbiota composition in general according to HPV status, we sought to examine if there were any differentially abundant taxa in HPV-negative and HPV-positive semen samples. Indeed, semen HPV status was associated with differences in the relative abundance of specific bacterial taxa. At phylum level, Fusobacteria were more abundant in HPV-negative (relative abundance: $0.450 \%)$ compared to HPV-positive (0.032\%) samples, $p=0.038$ (Fig. 2c). At family level, Streptococcaceae (relative abundance: $2.60 \%$ versus $1.27 \%, p=0.006$ ), Peptostreptococcaceae (0.49\% versus $0.063 \%, p=0.016)$, Veillonellaceae $(2.10 \%$ versus $0.80 \%, p=0.026)$ and Moraxellaceae $(1.45 \%$ versus $0.49 \%, p=0.028)$ were more abundant in the HPV-positive samples than in HPVnegative samples (Fig. 2d). HPV-positive samples presented higher relative abundance of the genera Streptococcus $(2.60 \%$ versus $1.27 \%, p=0.006)$, Serratia $(0.18 \%$ versus $0.01 \%, p=0.008)$, Dialister $(1.50 \%$ versus $0.42 \%$, $p=0.009)$ and Peptostreptococcus $(0.45 \%$ versus $0.039 \%$, $p=0.012)$ compared to HPV-negative semen samples (Fig. 2e). At OTU level, higher levels of Streptococcus oralis $(0.017 \%$ versus $0.00 \%, p=0.002)$, Anaerococcus mediterraneensis $(1.04 \%$ versus $0.12 \%, p=0.003)$ and Streptococcus anginosus $(0.025 \%$ versus $0.0016 \%, p=$ 0.011) were observed in the HPV-positive semen group relative to the HPV-negative group.

\section{Discussion}

In the present study, we detected that the presence of HPV in semen is associated with some detectable changes in the semen bacterial microbiota composition in healthy individuals. The bacterial microbiota of the semen samples consisted mainly of Comamonadaceae, Bifidobacteriaceae, Tissirellaceae, Corynebacteriaceae, Delftia, unclassified Comamonadeceae, Propionibacterium and Streptococcus members. The overall seminal bacterial composition has been seen to vary between different studies [13, 14]. Previous studies have reported that the genera Lactobacillus, Corynebacterium, Streptococcus, Pseudomonas, Prevotella and Gardenella mainly constitute the healthy/normal semen bacterial microbiota [13, 14, 17]. The bacterial composition in our semen samples were detected to be somewhat different compared to previous studies, but overall, the genera Corynebacterium and Streptococcus were consistent. The small sample size may have an effect on our results.

The semen microbiota can be influenced by the bacteria colonized the penis, urethra and from the urine $[12,19,26-30]$. Contamination from skin bacteria from the participants' hands is also possible. The circumcision status of the men is seen to change the penile microbiota composition as well [26, 28]. The Finnish Family HPV Study did not collect information about the male circumcision status, but in Finland it is not customary.

In the HPV-negative samples we detected higher abundance of Fusobacteria when compared to HPVpositive semen. Fusobacteria is a known oral pathogen [31] which has not, to authors' best knowledge, been detected in human semen samples before. In the female reproductive health, on the other hand, Fusobacteria have been detected to play a part in cervicovaginal dysbiosis and HPV persistence [32].

Given that semen HPV and microbiota has been implicated in seminal health and disease/disorders, including infertility $[10,11,13,19,33]$ and that the impact of HPV infection on semen microbiota remains unknown, we characterized the semen microbiota in presumably fertile men with and without HPV infection. All men in our study were presumably fertile, since they were recruited in the Finnish Family HPV Study as fathers-to-be. In our study cohort, the prevalence of HPV positivity in semen samples was $19.4 \%$. This was within the range (2 to $31 \%$ ) that has been reported in previous studies [4-6, 34, 35]. The prevalence of HPV has been reported to be slightly higher among men affected by unexplained infertility $[5$, 10, 36]. Furthermore, HPV infection has been associated with negative changes in semen quality including impairment of sperm motility and presence of anti-sperm antibodies [5, 37]. However, in our study, semen analysis (including sperm count test) was not performed to ascertain male fertility. 
A

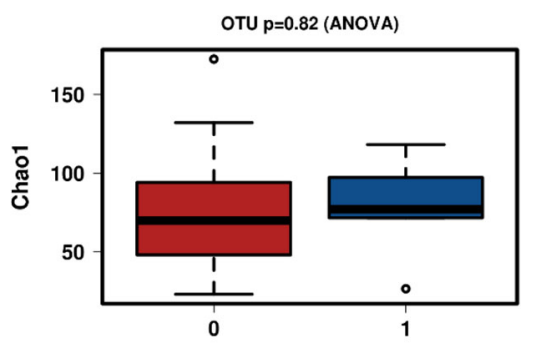

B

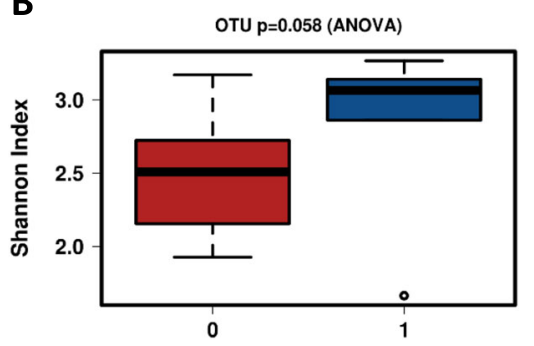

C

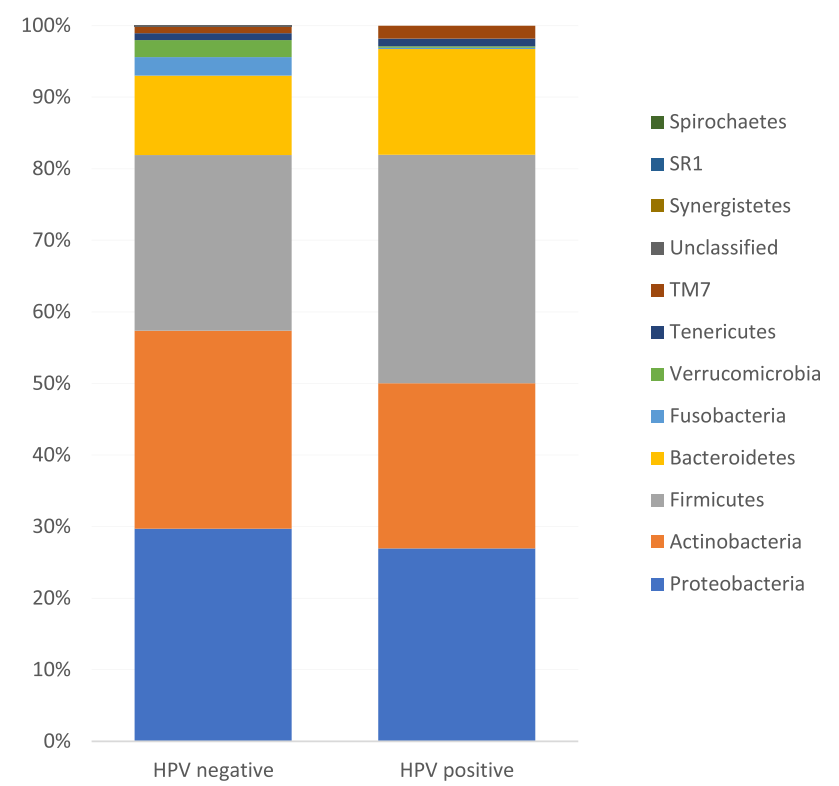

D

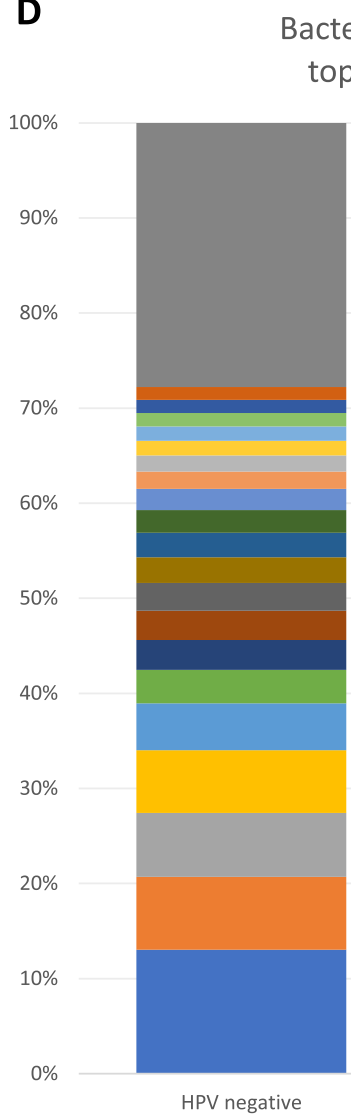

Bacterial composition, top 20 family level

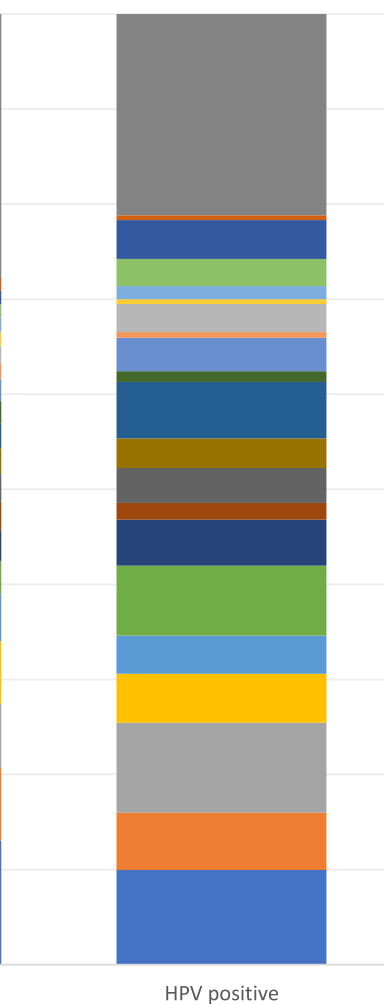

Bacterial composition,

phylum level 
In our study, we detected HPV-positive semen samples to be more abundant with Streptococcaceae, Peptostreptococcaceae, Veillonellaceae, in addition with Streptococcus, Serratia, Dialister and Peptostreptococcus (Supplementary Table 1). In line with our findings, present HR-HPV (high-risk HPV) infection has been connected with e.g. Prevotella and Dialister in one recent study [12]. Furthermore, asymptomatic STI (sexually transmitted infections) have been shown to be more frequent in male with specific bacterial urine microbiota (mainly with Prevotella and Veillonella) [29].

Previous studies have connected Lactobacillus, Streptococcus, Veillonella and Peptostreptococcus with undefined male infertility $[38,39]$. While HPV DNA found in semen has been linked to reduced semen quality, the abundances of Lactobacillus and Streptococcus have been identified to be significantly higher in semen samples from healthy men $[13,14]$. In contrast to the present study, HPV DNA positive semen samples were associated with an increase of e.g. Streptococcus and Peptostreptococcus genera as compared to HPV DNA negative semen. Among the bacterial microbiota found in semen, Ureaplasma has been described as a known pathogen connected strongly with male infertility [40]. Both HPV infection and certain bacterial species, such as Anaerococcus in semen have been associated in inferior semen quality in previous studies $[5,10,14,36]$. Male infertility is a complex multifactorial issue and cannot be explained by a single factor, such as HPV or presence of certain bacterial species. Furthermore, the connection between semen bacterial microbiota composition to male infertility is anything but simple [17]. Nevertheless, it is therefore important to understand how HPV and bacterial microbiota interact and what impact this interaction might have on male reproductive health.

Previously, it has been shown that present viral infection with HIV can shape the bacterial microbiota composition and that the altered bacterial composition might enable viral transmission in addition with changes in the pro-inflammatory cytokines [15]. It could be speculated that HPV might be able to interact with the bacterial microbiota in similar manner [33].

This study has some limitations. Our study design restricts us from making definitive conclusions about the viral-bacterial associations. Furthermore, the relatively low number of samples in general and the low number of HPV-positive semen samples may have an impact on the results, as we did not find significant impact of seminal HPV on the diversity of semen microbiota. HPV DNA may also originate from the proximal excurrent ducts (including efferent ductules, the vas epididymis and the proximal vas deferens) and not from HPVinfected seminal cells $[8,41]$. The small number of samples is a limitation of the study and does not allow generalized conclusions Furthermore, the time of abstinence is based only on the participant's own reports and might affect the sample quality and bacterial composition [18]. In addition, only the cellular fraction of the semen was used for DNA extraction and we cannot completely rule out that there could not be small traces of bacteria present in the seminal plasma. Nevertheless, this is the first study to show that seminal HPV infection is associated with high relative abundances of specific bacteria in the semen microbiota of presumably healthy men.

\section{Conclusions}

In this study, we showed that men with seminal HPV DNA had higher relative abundance of specific seminal bacteria compared to men without seminal HPV DNA, but the causal relationship remains to be determined in future studies. Furthermore, data is largely lacking on whether the interplay between seminal HPV and semen microbiota has any clinical significance in male reproductive health.

Improvement of semen quality and securing healthy semen microbiota may be among the beneficial effects of HPV vaccination. Recently, HPV vaccination has been shown to improve the clearing of semen HPV infections and the reproductive outcomes in infertile patients with semen HPV infection [42].

\section{Abbreviations}

FPL: Flat penile lesions; HPV: Human papillomavirus; HR-HPV: High-risk human papillomavirus; OUT: Operational taxonomic unit; PCoA: Principal coordinates analysis; PCR: Polymerase chain reaction; RDA: Redundancy analysis; STI: Sexually transmitted infections; TSS: Total sum normalization

\section{Supplementary Information}

The online version contains supplementary material available at https://doi. org/10.1186/s12879-021-06029-3.

Additional file 1: Table 1. The list of the samples.

Additional file 2: Supplementary Table 2. A) The most prevalent bacteria detected in HPV-negative semen samples. B) The most prevalent bacteria detected in HPV-positive semen samples.

Additional file 3: Supplementary Data 1. The beta-diversity estimations ( 0 = HPV-negative semen samples, $1=$ HPV-positive semen samples).

\section{Acknowledgements}

The authors wish to thank all the past and present members of the Finnish Family HPV Study, especially the families participating in this study. From the original Finnish Family Human Papillomavirus Study Group, the authors wish to especially thank Seija Grénman, Hanna-Mari Koskimaa, Karolina Louvanto, Anna Paaso, Marjut Rintala and Marja Sarkola. We also want to thank Ms.

Tatjana Peskova for her skillful help in the HPV MediCity Laboratory.

\section{Authors' contributions}

HT: Conceptualization, Methodology, Software, Formal analysis, Investigation, Resources, Data curation, Writing - Original draft, Visualization; JR Conceptualization, Methodology, Data curation, Writing - Review and editing, Supervision; KK: Data curation, Writing - Review and editing; SS: Conceptualization, Methodology, Software, Data curation, Writing - Review and editing; MCC: Methodology, Software, Formal analysis, Resources, Writing 
- Review and editing, Visualization; SR: Conceptualization, Methodology, Writing - Review and editing, Supervision. All authors have read and approved the manuscript.

\section{Funding}

Finnish Family HPV Study has been supported by the Academy of Finland, Finnish Cancer Foundation, Sohlberg Foundation, Finnish Dental Society, and the Government Special Foundation (EVO) to Turku University Hospital. The funders had no role in study design, data collection and analyses, decision to publish or preparation of the manuscript.

\section{Availability of data and materials}

The datasets used and/or analyzed during the current study are available from the corresponding author on reasonable request.

\section{Declarations}

\section{Ethics approval and consent to participate}

Written informed consent was obtained from all participants. The study design was found acceptable by the Ethics Committee of the Intermunicipal Hospital District of Southwest Finland (\#3/1998, \#2/2006, 45/180/2010).

\section{Consent for publication}

Not Applicable.

\section{Competing interests}

The authors report no conflict of interest.

\section{Author details}

${ }^{1}$ Department of Oral Pathology and Oral Radiology, Institute of Dentistry, Faculty of Medicine, University of Turku, Lemminkäisenkatu 2, FIN-20520 Turku, Finland. 'Department of Oral and Maxillofacial Diseases, Clinicum, Faculty of Medicine, University of Helsinki and Helsinki University Hospital, Helsinki, Finland. ${ }^{3}$ Department of Pathology, Medicum, Faculty of Medicine, University of Helsinki and HUS Diagnostic Center, HUSLAB, Helsinki University Hospital, Helsinki, Finland. ${ }^{4}$ Department of Obstetrics and Gynaecology, University of Turku \& Turku University Hospital, Turku, Finland. ${ }^{5}$ Department of Pathology, Turku University Hospital, Turku, Finland. ${ }^{6}$ Department of Biotechnology, Institute of Agrochemistry and Food Science, Spanish National Research Council (IATA-CSIC), Valencia, Spain. ${ }^{7}$ Department of Paediatrics, University of Turku \& Turku University Hospital, Turku, Finland. ${ }^{8}$ Department of Pediatrics, University of Helsinki \& Helsinki University Hospital, Helsinki, Finland.

Received: 25 December 2020 Accepted: 31 March 2021 Published online: 21 April 2021

\section{References}

1. Giuliano AR, Nyitray AG, Kreimer AR, Cambell CMP, Goodman MT, Sudenga SL, et al. EUROGIN 2014 roadmap: differences in human papillomavirus infection natural history, transmission and human papillomavirus-related cancer incidence by gender and anatomic site of infection. Int J Cancer. 2015;136(12):2752-60. https://doi.org/10.1002/ijc.29082.

2. Tuominen H, Rautava S, Collado MC, Syrjänen S, Rautava J. HPV infection and bacterial microbiota in breast milk and infant oral mucosa. PLoS One. 2018;13:e0207016 Available from: http://www.ncbi.nlm.nih.gov/pubmed/303 95655. [cited 2018 Dec 20].

3. Tuominen H, Rautava S, Syrjänen S, Collado MC, Rautava J. HPV infection and bacterial microbiota in the placenta, uterine cervix and oral mucosa. Sci Rep. 2018:8:9787 Available from: http://www.nature.com/articles/s41598-01 8-27980-3. Nature Publishing Group;[cited 2018 Jul 5].

4. Rintala MAM, Greénman SE, Pöllänen PP, Suominen JJO, Syrjänen SM, Grénman SE, et al. Detection of high-risk HPV DNA in semen and its association with the quality of semen. 2004;15 Available from: http://www. ncbi.nlm.nih.gov/pubmed/15537460.[cited 2016 Aug 19].

5. Foresta C, Noventa M, De Toni L, Gizzo S, Garolla A. HPV-DNA sperm infection and infertility: from a systematic literature review to a possible clinical management proposal. Andrology. $2015 ; 3: 163-173$. Available from: https://doi.org/10.1111/andr.284. [cited 2018 Jan 17]

6. Schillaci R, Capra G, Bellavia C, Ruvolo G, Scazzone C, Venezia R, et al. Detection of oncogenic human papillomavirus genotypes on spermatozoa from male partners of infertile couples. Fertil Steril. 2013;100:1236-40 Available from: http://linkinghub.elsevier.com/retrieve/pii/S001502821300742 5. [cited 2018 Jan 17].

7. Kero K, Rautava J, Syrjänen K, Grenman S, Syrjänen S. Human papillomavirus genotypes in male genitalia and their concordance among pregnant spouses participating in the finnish family HPV Study. J Sex Med. 2011;8: 2522-31 Available from: http://www.ncbi.n/m.nih.gov/pubmed/21718450. [cited 2018 Jan 17].

8. Luttmer R, Dijkstra MG, Snijders PJF, Jordanova ES, King AJ, Pronk DTM, et al. Presence of human papillomavirus in semen of healthy men is firmly associated with HPV infections of the penile epithelium. Fertil Steril. 2015; 104:838-844.e8 Available from: http://linkinghub.elsevier.com/retrieve/pii/ S0015028215004550. [cited 2018 Jan 17].

9. Foresta C, Bertoldo A, Garolla A, Pizzol D, Mason S, Lenzi A, et al. Human papillomavirus proteins are found in peripheral blood and semen $\mathrm{Cd} 20+$ and Cd56+ cells during Hpv-16 semen infection. BMC Infect Dis. 2013;13: 593 Available from: http://www.ncbi.nlm.nih.gov/pubmed/24341689. [cited 2018 Jan 17].

10. Souho T, Benlemlih M, Bennani B. Human papillomavirus infection and fertility alteration: a systematic review. Harper DM, editor. PLoS One. 2015; 10:e0126936 Available from: http://www.ncbi.nlm.nih.gov/pubmed/25992 782. [cited 2018 Jan 17].

11. Depuydt CE, Donders GGG, Verstraete L, Vanden Broeck D, Beert JFA, Salembier $\mathrm{G}$, et al. Infectious human papillomavirus virions in semen reduce clinical pregnancy rates in women undergoing intrauterine insemination. Fertil Steril. 2019;111:1135-44 Available from: http://www.ncbi.nlm.nih.gov/ pubmed/31005311. [cited 2020 Oct 18]

12. Onywera H, Williamson AL, Cozzuto L, Bonnin S, Mbulawa ZZA, Coetzee D, et al. The penile microbiota of Black South African men: Relationship with human papillomavirus and HIV infection. BMC Microbiol. 2020;20:78 Available from: https://bmcmicrobiol.biomedcentral.com/articles/10.1186/ s12866-020-01759-x. BioMed Central Ltd.; [cited 2021 Feb 24].

13. Weng S-L, Chiu C-M, Lin F-M, Huang W-C, Liang C, Yang T, et al. Bacterial communities in semen from men of infertile couples: metagenomic sequencing reveals relationships of seminal microbiota to semen quality. Abdo Z, editor. PLoS One. 2014;9:e110152 Available from: http://www.ncbi. nlm.nih.gov/pubmed/25340531. [cited 2018 Jan 17].

14. Hou D, Zhou X, Zhong X, Settles ML, Herring J, Wang L, et al. Microbiota of the seminal fluid from healthy and infertile men. Fertil Steril. 2013;100:12611269.e3 Available from: http://www.ncbi.nlm.nih.gov/pubmed/23993888. [cited 2018 Jan 17].

15. Liu CM, Osborne BJW, Hungate BA, Shahabi K, Huibner S, Lester R, et al. The semen microbiome and its relationship with local immunology and viral load in HIV infection. PLoS Pathog. 2014;10 Available from: https://pubmed. ncbi.n/m.nih.gov/25058515/. Public Library of Science. [cited 2021 Feb 24].

16. Mändar R, Punab M, Korrovits P, Türk S, Ausmees K, Lapp E, et al. Seminal microbiome in men with and without prostatitis. Int J Urol. 2017;24:211-6 Available from: https://pubmed.ncbi.nlm.nih.gov/28147438/. Blackwell Publishing; [cited 2021 Feb 24].

17. Baud D, Pattaroni C, Vulliemoz N, Castella V, Marsland BJ, Stojanov M. Sperm microbiota and its impact on semen parameters. Front Microbiol. 2019;10 Available from: /pmc/articles/PMC6379293/. Frontiers Media S.;.; [cited 2021 Feb 24].

18. Mändar R, Punab M, Borovkova N, Lapp E, Kiiker R, Korrovits P, et al. Complementary seminovaginal microbiome in couples. Res Microbiol. 2015; 166(5):440-7. https://doi.org/10.1016/j.resmic.2015.03.009.

19. Altmäe S, Franasiak JM, Mändar R. The seminal microbiome in health and disease. Nat Rev Urol. 2019;16:703-21 Available from: http://www.nature.com/a rticles/s41585-019-0250-y. Nature Publishing Group; [cited 2020 Jul 16].

20. Rintala M, Grénman, Puranen, Isolauri, Ekblad, Kero, et al. Transmission of high-risk human papillomavirus (HPV) between parents and infant: a prospective study of HPV in families in Finland. J Clin Microbiol. 2005 43: 376-381. Available from: http://www.ncbi.nlm.nih.gov/pubmed/15634997. [cited 2019 Mar 15]

21. Rautava J, Willberg J, Louvanto K, Wideman L, Syrjänen K, Grénman S, et al. Prevalence, genotype distribution and persistence of human papillomavirus in oral mucosa of women: a six-year follow-up study. Ramqvist T, editor. PLoS One. 2012;7:e42171 Available from: http://www.ncbi.nlm.nih.gov/ pubmed/22952591. Public Library of Science; [cited 2016 Aug 19].

22. Tuominen H, Collado MC, Rautava J, Syrjänen S, Rautava S. Composition and maternal origin of the neonatal oral cavity microbiota. J Oral Microbiol. 2019;11(1). https://doi.org/10.1080/20002297.2019.1663084. 
23. DeSantis TZ, Hugenholtz P, Larsen N, Rojas M, Brodie EL, Keller K, et al. Greengenes, a chimera-checked $16 \mathrm{~S}$ rRNA gene database and workbench compatible with ARB. Appl Environ Microbiol. 2006;72:5069-72 Available from: https://pubmed.ncbi.nlm.nih.gov/16820507/. [cited 2021 Feb 24].

24. Caporaso JG, Kuczynski J, Stombaugh J, Bittinger K, Bushman FD, Costello EK, et al. QIIME allows analysis of high-throughput community sequencing data. Nat Methods. 2010;7(5):335-6. https://doi.org/10.1038/nmeth.f.303.

25. Zakrzewski M, Proietti C, Ellis JJ, Hasan S, Brion MJ, Berger B, et al. Calypso: A user-friendly web-server for mining and visualizing microbiome-environment interactions. Bioinformatics. 2017;33:782-3 Available from: https://pubmed.ncbi. nlm.nih.gov/28025202/. Oxford University Press; [cited 2021 Feb 24].

26. Price LB, Liu CM, Johnson KE, Aziz M, Lau MK, Bowers J, et al. The effects of circumcision on the penis microbiome. PLoS One. 2010;5 Available from: https://pubmed.ncbi.nlm.nih.gov/20066050/. [cited 2021 Mar 10].

27. Plummer EL, Vodstrcil LA, Danielewski JA, Murray GL, Fairley CK, Garland SM, et al. Combined oral and topical antimicrobial therapy for male partners of women with bacterial vaginosis: acceptability, tolerability and impact on the genital microbiota of couples - a pilot study. PLoS One. 2018;13 Available from: https://pubmed.ncbi.nlm.nih.gov/29293559/. Public Library of Science. [cited 2021 Mar 10].

28. Nelson DE, Dong Q, van der Pol B, Toh E, Fan B, Katz BP, et al. Bacterial communities of the coronal sulcus and distal urethra of adolescent males. PLoS One. 2012;7 Available from: https://pubmed.ncbi.nlm.nih.gov/226062 51/. [cited 2021 Mar 10].

29. Nelson DE, van der Pol B, Dong Q, Revanna KV, Fan B, Easwaran S, et al. Characteristic male urine microbiomes associate with asymptomatic sexually transmitted infection. PLoS One, PLoS One. 2010;5 Available from: https://pubmed.ncbi.nlm.nih.gov/21124791/. [cited 2021 Mar 10].

30. Dong Q, Nelson DE, Toh E, Diao L, Gao X, Fortenberry JD, et al. The microbial communities in male first catch urine are highly similar to those in paired urethral swab specimens. PLoS One. 2011;6 Available from: https://pubmed.ncbi.nlm.nih.gov/21603636/. [cited 2021 Mar 10].

31. Tuominen $\mathrm{H}$, Rautava J. Oral microbiota and cancer development. Pathobiology. 2020; Available from: https://pubmed.ncbi.nlm.nih.gov/331 76328/. S. Karger AG; [cited 2021 Mar 10].

32. Qingqing B, Jie Z, Songben Q, Juan C, Lei Z, Mu X. Cervicovaginal microbiota dysbiosis correlates with HPV persistent infection. Microb Pathog. 2020;152:104617 Academic Press.

33. Lyu Z, Feng X, Li N, Zhao W, Wei L, Chen Y, et al. Human papillomavirus in semen and the risk for male infertility: A systematic review and metaanalysis. BMC Infect Dis. 2017;17 Available from: https://pubmed.ncbi.nlm. nih.gov/29121862/. BioMed Central Ltd.; [cited 2021 Mar 10].

34. Luttmer R, Dijkstra MG, Snijders PJF, Hompes PGA, Pronk DTM, Hubeek I, et al. Presence of human papillomavirus in semen in relation to semen quality. Hum Reprod. 2016;31:dev317 Available from: http://www.ncbi.nlm. nih.gov/pubmed/26724799. [cited 2017 Mar 19].

35. Laprise C, Trottier H, Monnier P, Coutlee F, Mayrand M-H. Prevalence of human papillomaviruses in semen: a systematic review and meta-analysis. Hum Reprod. 2014;29:640-51 Available from: http://www.ncbi.nlm.nih.gov/ pubmed/24365799. [cited 2018 Jan 17].

36. Capra G, Schillaci R, Bosco L, Roccheri MC, Perino A, Ragusa MA. HPV infection in semen: results from a new molecular approach. Epidemiol Infect. 2019;147:e177 Available from: http://www.ncbi.nlm.nih.gov/ pubmed/31063107. [cited 2020 Jul 16].

37. Zacharis K, Messini Cl, Anifandis G, Koukoulis G, Satra M, Daponte A. Human Papilloma Virus (HPV) and fertilization: a mini review. Medicina (Kaunas). 2018;54 Available from: http://www.ncbi.n/m.nih.gov/pubmed/30344281. [cited 2020 Jul 16].

38. Kiessling AA, Desmarais BM, Yin H-Z, Loverde J, Eyre RC. Detection and identification of bacterial DNA in semen. Fertil Steril. 2008;90:1744-56 Available from: www.ncbi.nih. [cited 2020 Jul 16]

39. Marchandin H, Teyssier C, Jumas-Bilak E, Robert M, Artigues A-C, Jean-Pierre $\mathrm{H}$. Molecular identification of the first human isolate belonging to the Veillonella ratti-Veillonella criceti group based on 165 rDNA and dnaK gene sequencing. Res Microbiol. 2005;156:603-7 Available from: https://www. sciencedirect.com/science/article/pii/S0923250805000240. Elsevier Masson; [cited 2020 Jul 16]

40. Filipiak E, Marchlewska K, Oszukowska E, Walczak-Jedrzejowska R, Swierczynska-Cieplucha A, Kula K, et al. Presence of aerobic microorganisms and their influence on basic semen parameters in infertile men. Andrologia. 2015 ;47:826-831. Available from: https://doi.org/10.1111/a nd.12338. Wiley; [cited 2020 Jul 16].
41. Rintala MAM, Pöllänen PP, Nikkanen VP, Grénman SE, Syrjänen SM. Human papillomavirus DNA is found in the vas Deferens. J Infect Dis. 2002;185: 1664-7 Available from: https://academic.oup.com/jid/article-lookup/doi/10.1 086/340421. Oxford Academic; [cited 2021 Mar 17].

42. Foresta C, Garolla A, Parisi S, Ghezzi M, Bertoldo A, Di Nisio A, et al. HPV prophylactic vaccination in males improves the clearance of semen infection. EBioMedicine. 2015;2:1487-93 Available from: http://www.ncbi. nlm.nih.gov/pubmed/26629543. [cited 2020 Jul 16].

\section{Publisher's Note}

Springer Nature remains neutral with regard to jurisdictional claims in published maps and institutional affiliations.
Ready to submit your research? Choose BMC and benefit from:

- fast, convenient online submission

- thorough peer review by experienced researchers in your field

- rapid publication on acceptance

- support for research data, including large and complex data types

- gold Open Access which fosters wider collaboration and increased citations

- maximum visibility for your research: over $100 \mathrm{M}$ website views per year

At BMC, research is always in progress.

Learn more biomedcentral.com/submissions 